\title{
Microorganisms associated with the house-dust mite, Dermatophagoides*
}

\author{
Heinan $\mathrm{OH},{ }^{* *}$ Akira Ishil, ${ }^{* *}$ Yasumasa Tongu ${ }^{* *}$ and Kazuo ITAno** \\ Department of Parasitology, Okayama University Medical School, \\ 2-5-1 Shikata-cho, Okayama 700, Japan
}

(Received: December 5, 1985)

Key words: house-dust mite, Dermatophagoides, bacteria, fungi, Kawasaki disease, asthma.

\begin{abstract}
Bacteria and fungi associated with the house-dust mite Dermatophagoides were investigated. The house-dust mites were washed with sterile distilled water and homogenized. Bacterial count, isolation and identification of the bacteria and fungi were made with routine laboratory methods for medical pathogens. The number of bacteria counted per 100 mites in positive samples was 12.7 for laboratory-bred Dermatophagoides pteronyssinus and Dermatophagoides farinae, more than 121 for mites from control houses, and more than 66 and 121 for those from houses with asthmatic and Kawasaki disease patients, respectively. The bacteria isolated from the house-dust mites were Bacillus spp., Staphylococcus spp., Gramnegative non-fermenting rods and Gram-positive coryneform rods. As for fungi, Aspergillus spp., Penicillium spp., Cladosporium spp., Alternaria spp., Acremonium spp., Paecilomyces spp. and yeasts were isolated. All of those microorganisms found were indigenous microbes and there was no particular difference in their occurrence between the house-dust mites from control houses and those from houses with asthmatic or Kawasaki disease patients. The public health importance of the house-dust mites as a possible vector of the microorganisms was discussed.
\end{abstract}

\section{INTRODUCTION}

The house-dust mites, Dermatophagoides pteronyssinus (D. p.) and Dermatophagoides farinae (D. f.) are known to be the most common allergen of bronchial asthma and allergic rhinitis (Ishii, 1975; Wharton,

* This study was supported by a Grant-in-Aid for Scientific Research from the Ministry of Education and Culture of Japan (No. 58480169).

** 王 炳楠, 石井 明, 頓宮廉正, 板野一男: 岡山 大学医学部寄生虫学教室 (广T700 岡山祘岡山市鹿 田町 2-5-1)
1976). In connection with these allergic diseases, many studies have been made also on fungal flora in the house dust or in the air, and on the influence of bacteria or fungi on the growth of the house-dust mites (van Bronswijk et al., 1973; Davies, 1930; Ishii et al., 1979; Lustgraaf, 1979; Solomon, 1975; Takahashi and Tanie, 1974). The bacterial floras of house-dust mites have been studied particularly in search for the causative agent(s) of Kawasaki disease (MCLS, mucocutaneous lymphnode syndrom) in Japan (Hamashima et al., 1973; Ishii et al., 1983; Kato et al., 1983; Ushijima et al., 1983).

In the present study, we isolated and 
compared the microorganisms associated with Dermatophagoides in the house dust from control houses with those from houses with asthmatic or Kawasaki disease patients.

\section{Materials and Methods}

House dust and the house dust mites: Eight dust samples from control houses and 15 dust samples each from houses of asthmatic or Kawasaki disease patients were used in this study. The dust samples have been kept at $-20^{\circ} \mathrm{C}$ until testing. The frozen materials were brought up rapidly to 30 to $35^{\circ} \mathrm{C}$ in a water-bath before testing. Fine dust was obtained by sieving with a combination of 9- and 200-mesh sieves mechanically. The fine dust retained on the 200-mesh sieve was suspended in a 500-ml Wildman flask containing saturated $\mathrm{NaCl}$ solution, and stirred for $10 \mathrm{~min}$ and then filtered through a combination of 80 - and 170 -mesh sieves under the pressure of running water. The fine dust retained on both 80- and 170-mesh sieves was filtered with filter paper by suction.

Among the mites retained on the filter paper, adult D.p. and D.f. were picked up with a needle under a stereomicroscope onto sterile filter paper and their number was counted. The house-dust mites were subsequently washed several times with sterile distilled water by suction. The laboratorybred D.p. and D.f. were collected from 6 lots of culture by saline flotation method described by Shimomura et al. (1982) and processed as described above. The laboratory-bred D.p. and D.f. were reared on an equal amount of powdered animal food (Clea Co., Tokyo) and dry yeast (Ebios, Tanabe Pharmaceutical Co., Ltd.) (Miyamoto et al., 1975). The culture was maintained at $25^{\circ} \mathrm{C}$ under the atmosphere of $75 \%$, R.H.

Media used: The following commercially available dehydrated media were used for the preparation of test media. Culture bottle, No. 5 (Eiken Chemical Co., Tokyo, Japan), thioglycollate medium (TGY) (Eiken Chemical Co.), blood (rabbit) agar plates (Japanese Center for Biologic Materials, Ltd., Tokyo, Japan), MacConkey agar medium (Difco Laboratories, U.S.A.), Sabouraud's dextrose agar medium (Eiken Chemical Co.), heart-infusion agar medium (Eiken Chemical Co.), Simmon's citrate agar (Eiken Chemical Co.), Trypto-soya broth (Nissui Pharmaceutical Co. Ltd., Tokyo, Japan), triple sugar iron agar medium (Difco Laboratories), OF basal medium (Difco Laboratory), egg medium (prepared in the laboratory).

Inoculum: The washed mites were suspended in $3 \mathrm{ml}$ Trypto-soya broth and homogenized mechanically with a tissuegrinder in an ice-water bath for $5 \mathrm{~min}$. We attempted to examine 100 mites from each sample, but in some cases, we could not obtain sufficient number from every sample. The actual number of mites examined was $57(17-100), 48(5-100), 62(20-100)$ in average for the control group, asthmatic patients group and Kawasaki disease patients group, respectively. For laboratory-bred D.p. and $D . f ., 100$ mites from each lot of cultures were examined.

Bacterial count: One $\mathrm{ml}$ of the homogenate was thoroughly mixed with heartinfusion agar that was maintained at $46^{\circ} \mathrm{C}$. The mixed plates were incubated, after solidification, at $35^{\circ} \mathrm{C}$ for $48 \mathrm{hr}$. Colonies which developed were counted with the aid of a magnifier.

Isolation of bacteria: Bacteria were isolated by inoculating $1.0 \mathrm{ml}$ mite-homogenate into culture bottle No. 5 or thioglycollate broth. The culture was incubated at $35^{\circ} \mathrm{C}$ until a visible growth. No growth after 1 week incubation was considered as negative. A loopful of the turbulant culture was streaked on blood agar, MacConkey agar and nutrient agar plates for isolation. The identification of bacteria was mainly based on Cowan and Steel (1974). The criteria used are shown in Table 1.

Isolation of fungi: About $0.05 \mathrm{ml}$ each of the homogenates was streaked on Sabouraud's dextrose agar plates. The inoculated plates were incubated at $25^{\circ} \mathrm{C}$ under the atmosphere of $100 \%$ R.H. Positive cultures were processed to identification by slide culture. Lactophenol Cotton Blue solution was used for staining fungi.

Figure 1 presents the outline of the pro- 
Table 1 Criteria used for preliminary identification of microorganisms.

$\begin{array}{ll}\text { A. For Gram-negative bacteria } & \text { G. For Bacillus species } \\ \text { 1. Shape } & \text { 1. Gram-positive/Gram-variant rods } \\ \text { 2. Motility } & \text { 2. Morphology of spore } \\ \text { 3. Growth in air } & \text { 3. Lecithinase production } \\ \text { 4. Growth anaerobically } & \text { 4. Citrate utilization } \\ \text { 5. Catalase } & \text { 5. Anaerobic growth } \\ \text { 6. Oxidase } & \\ \text { 7. Glucose (acid) } & \text { D. For non-fermentative Gram-negative bacilli } \\ \text { 8. Oxidation-fermentation (OF) } & \text { 1. Oxidase glucose } \\ \text { B. For Gram-positive bacteria } & \text { 2. Growth on MacConkey agar } \\ \text { 1. Shape } & \text { 3. Oxidase production } \\ \text { 2. Acid fast } & \\ \text { 3. Spore } & \\ \text { 4. Motility } & \\ \text { 5. Growth in air } & \\ \text { 6. Growth anaerobically } & \\ \text { 7. Catalase } & \end{array}$

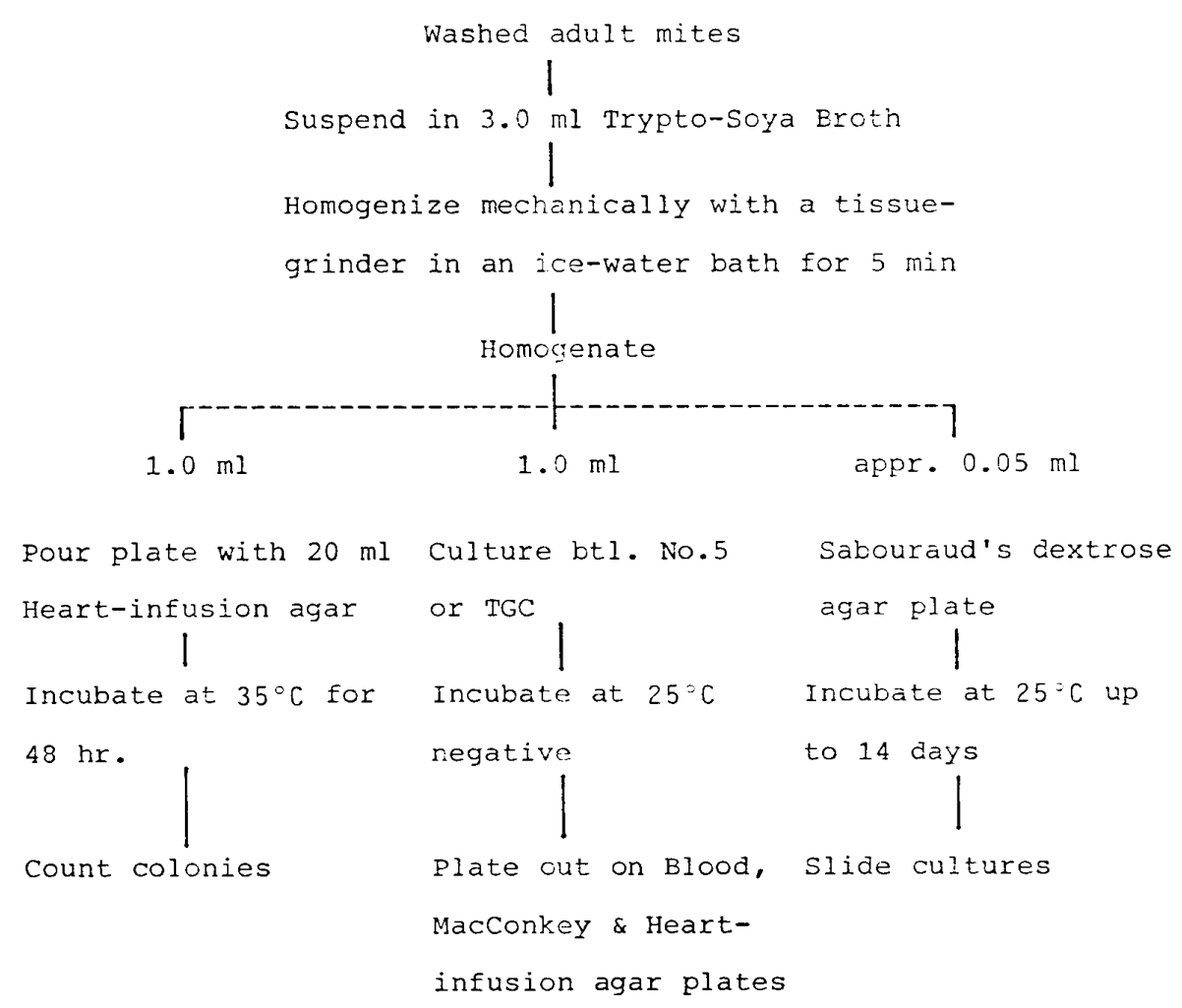

Fig. 1 Method for the examination of microorganisms in house-dust and cultured mites. 
cedure used.

\section{Results}

The number of bacteria isolated from the house-dust mites

Positive growths were obtained in all samples of the laboratory-bred D.p. and D.f., in 5 out of 8 samples collected from the control houses, and in 8 out of 15 samples each from the houses with asthmatics or MCLSs patients. Bacterial count for 100 mites of the positive samples in the groups of laboratorybred D.p. and D.f., control houses, houses with asthmatic patients and those of Kawasaki disease patients was $12,7,121+, 66+$ and 121 , respectively (Table 2 ). The plus sign indicates that uncountable colonies developed in one of the samples in the group. The number of bacteria in both laboratorybred D.p. and D.f. was much less than those in the other three groups, among which no significant difference was observed.

\section{Bacteria isolated from the mites}

A total of 27 strains of Bacillus (B. cereus and other bacilli), Staphylococcus, Gramnegative non-fermenting rods and coryneform Gram-positive rods were isolated. The frequencies of their occurrence were $48 \%$ or $13 / 27$ for Bacillus, $44 \%$ or $12 / 27$ for Staphylococcus, $4 \%$ or $1 / 27$ for Gramnegative non-fermenting rods and $4 \%$ or $1 / 27$ for coryneform Gram-positive rods.

In the group of laboratory-bred D.p. and D.f., 11 strains of two genera, Bacillus and Staphylococcus were isolated. Amongst them, B. cereus and Staphylococcus were predominant $(5 / 11$ or $45 \%$ each).

In the control group, Gram-positive sporeforming bacilli (other than B. cereus), Staphylococcus, Gram-negative non-fermenting rods and coryneform Gram-positive rods were isolated once each $(1 / 4$ or $25 \%)$. On the other hand, Gram-positive spore-forming bacilli (other than B. cereus) ( $3 / 6$ or $50 \%)$, and Staphylococcus $(3 / 6$ or $50 \%)$ were isolated in both groups of the asthmatics and MCLSs. Bacillus and Staphylococcus were commonly isolated in the house-dust mites from all the groups including the laboratory-bred D.p. and D.f.

\section{Fungi isolated}

Aspergillus, Penicillium, Cladosporium, Alternaria, Acremonium, Paecilomyces and yeasts were isolated at frequences of $31 \%$ $(8 / 26), 27 \%,(7 / 26), 19 \%(5 / 26), 11 \%$ $(3 / 26), 4 \%(1 / 26), 4 \%(1 / 26)$ and $4 \%$ $(1 / 26)$, respectively (Table 3$)$. Aspergillus, Cladosporium and Penicillium were commonly isolated from the house-dust mites of all the groups except the laboratory-bred $D . p$. and D.f., in which only Cladosporium was detected. In the group of control houses, 8 strains of fungi were isolated. Amongst them, Aspergillus was predominant (4/8 or 50\%). Clad'osporium, Penicillium, Paecilomyces and yeasts were also isolated once each. In the group of asthmatics, 8 strains consisting of Aspergillus, Cladosporium, Penicillium, Alternaria, Acremonium, and yeasts were isolated. On the other hand, 8 strains consisting of Aspergillus, Clado-

Table 2 Number of bacteria isolated from house-dust mites.

\begin{tabular}{cccccccc} 
Source & $\begin{array}{c}\text { Number } \\
\text { of } \\
\text { sample }\end{array}$ & $\begin{array}{c}\text { Pos. } \\
\text { samples }\end{array}$ & $\begin{array}{c}\% \text { pos. } \\
\text { sample }\end{array}$ & $\begin{array}{c}\text { Total } \\
\text { mites }\end{array}$ & $\begin{array}{c}\text { No. of } \\
\text { mites in } \\
\text { pos. sample }\end{array}$ & $\begin{array}{c}\text { Total } \\
\text { number } \\
\text { bact. }\end{array}$ & $\begin{array}{c}\text { Bacteria } \\
\text { per 100 } \\
\text { pos. mite }\end{array}$ \\
\hline Lab.-bred & & & & & & & \\
$\quad$. $f$. & 3 & 3 & 100 & 300 & 300 & 36 & 12 \\
D. $p$. & 3 & 3 & 100 & 300 & 300 & 21 & 7 \\
Normal & 8 & 5 & 62.5 & 452 & 382 & $465+^{*}$ & $121+$ \\
Asthmatics & 15 & 8 & 53.3 & 729 & 531 & $339+$ & $66+$ \\
MCLSs** & 15 & 8 & 53.3 & 937 & 490 & 591 & 121 \\
\hline
\end{tabular}

* The plus sign indicates that an uncountable bacterial growth was obtained in one sample.

** Mucocutaneous lymphnode syndrome. 
Table 3 Kind and occurrence of microorganism isolated in the house-dust mites.

\begin{tabular}{|c|c|c|c|c|c|c|}
\hline \multirow{3}{*}{ Microorganism } & \multicolumn{6}{|c|}{ Sample (number) } \\
\hline & \multicolumn{2}{|c|}{ Lab.-bred } & \multirow{2}{*}{$\begin{array}{c}\text { Normal } \\
\text { houses } \\
\quad(8)\end{array}$} & \multirow{2}{*}{$\begin{array}{l}\text { Asthmatics } \\
\text { (15) }\end{array}$} & \multirow{2}{*}{$\begin{array}{c}\text { MCLSs } \\
(15)\end{array}$} & \multirow{2}{*}{$\begin{array}{c}\text { Total } \\
\text { number }\end{array}$} \\
\hline & $\underset{(6)}{D . p .}$ & $\underset{(6)}{D . f .}$ & & & & \\
\hline \multicolumn{7}{|l|}{ I. Bacteria } \\
\hline B. cereus & 3 & 2 & 0 & 0 & 0 & 5 \\
\hline Other bacilli & 1 & 0 & 1 & 3 & 3 & 8 \\
\hline Staphylococcus & 2 & 3 & 1 & 3 & 3 & 12 \\
\hline Gram-neg. non-fermenting rods & 0 & 0 & 1 & 0 & 0 & 1 \\
\hline Coryneform Gram-pos. rods & 0 & 0 & 1 & 0 & 0 & 1 \\
\hline \multicolumn{7}{|l|}{ II. Fungi } \\
\hline Aspergillus & 0 & 0 & 4 & 1 & 3 & 8 \\
\hline Cladosporium & 1 & 1 & 1 & 2 & 2 & 7 \\
\hline Penicillium & 0 & 0 & 1 & 2 & 2 & 5 \\
\hline Alternaria & 0 & 0 & 0 & 1 & 0 & 1 \\
\hline Acremonium & 0 & 0 & 0 & 1 & 0 & 1 \\
\hline Paecilomyces & 0 & 0 & 1 & 0 & 0 & 1 \\
\hline yeast & 0 & 0 & 1 & 1 & 1 & 3 \\
\hline
\end{tabular}

The figure denotes the number of positive samples from which the specific microorganism was isolated.

sporium, Penicillium and yeasts were isolated in house-dust mites from houses with Kawasaki disease patients, with Aspergillus being predominant. Cladosporium and Penicillium were also isolated each at a frequency of $25 \%(2 / 8)$.

\section{Discussion}

In search for the causative agent(s) of Kawasaki disease, Hamashima et al. (1982) described rickettsia-like bodies found by electron microscopy in the skin biopsies as well as in the digestive canal of the mites collected from house dust of Kawasaki disease patient houses.

Ushijima et al. (1983) reported that microorganism-like particles were found by electron microscopy in the digestive tracts of house-dust mites from 5 Kawasaki disease patients. The same authors also reported that some bacteria such as Achromobacter xylosoxidans, Flabobacterium IIb, Candida guilliermondi, Pseudomonas aeruginosa, Pseudomonas putida, Pseudomonas stutzeri, Serratia marcescens, Citrobacter freundii and Enterobacter cloacae were found in the house-dust mites of the same origin. whereas
Staphylococcus epidermides, Pseudomonas spp. and Bacillus were found in the mites of the control.

On the other hand, Kato et al. (1983) reported that 20 species of bacteria and 2 kinds of fungi were isolated from the housedust mites, although most of them are of no medical importance except Staphylococcus epidermidis, Bacillus subtilis, and Pseudomonas spp. Moreover, they also isolated Propionibacterium acnes, an obligate anaerobe, from a homogenate of the mite samples from house dust collected from houses with Kawasaki disease patients.

We found, by culturing the mite homogenates, 4 kinds of bacteria and 7 fungal genera in the house-dust mites from various sources as described. Our bacterial flora includes Bacillus spp., Staphylococcus spp.. and unidentified Gram-negative and Grampositive rods. The 7 fungal genera are represented by the species already recognized as the causative agents of allergic diseases. The number and species of bacteria and fungi were found fewer in the laboratorybred Dermatophagoides than in the other sources. This may be caused by the procedure of heating the media for mites culture 
at $120^{\circ} \mathrm{G}$ for $1 \mathrm{hr}$.

There was no appreciable difference in the bacterial count, the types and relative abundance of the bacteria and fungi among the house-dust mites from control houses, and houses with asthmatic or Kawasaki disease patients. We have isolated fewer bacterial species than those reported by the previous authors. We believe that this was caused by the difference in time or locality of sample collection. Although our samples have been kept frozen at $-20^{\circ} \mathrm{C}$ and some delicate bacteria might have died out, we could recover spore-forming bacteria and fungi similar to those described by the previous authors.

As for fungi, Ishii et al. (1979) reported that Penicillium, Aspergillus, Trichoderma, Cladosporium, Phoma, Wallemia and Alternaria were isolated from the house dust samples collected from control houses and houses with asthmatic patients, with or without positive skin tests. They also described that Penicillium and Cladosporium were most predominant $(93 \%)$ in all the 3 groups of the dusts in their study. We found that Penicillium spp. and Cladosporium spp. were equally predominant in the house-dust mites from the houses with asthmatic patients. On the other hand, Aspergillus was predominant in those from the houses with MCLS patients, although it was widely isolated from the house-dust mites in the control houses. The fungi isolated by us were similar to those isolated from house dust by Ishii et al. (1979). This suggests that the microbes associated with the mites are greatly influenced by their habitats. The isolation of obligate anaerobes was not attempted in this study.

One of us could not demonstrate the evidence of blood sucking nor bite by the mite, Dermatophagoides, pteronyssinus, despite on exposure on the skin of 4 volunteers for $4 \mathrm{hr}$ and morphological characteristics of the mite do not show any structural suitability for bite or piercing the skin. It is unlikely that the house-dust mites would serve as a vector of diseases by biting, although they harbour microbes and might transmit diseases. The microorganisms, so far examined and associated with the house-dust mites, were indigenous microbes in the environment and no particular difference in microorganisms was observed among the house-dust mites collected from control houses, houses with asthmatic patients and those with Kawasaki disease patients.

\section{Acknowledgements}

We thank Prof. Y. Kanemasa, Department of Bacteriology for his review of the manuscript.

\section{REFERENCES}

Cowan, S. T. and K. J. Steel (1974): Manual of Identification of Medical Bacteria, 2nd ed., Cambridge University Press, Cambridge.

Davies, R. R. (1930): Viable molds in house dust. Trans. Br. Mycol. Soc., 43: 617-630.

Hamashima, Y., K. Kishi and K. Tasaka (1973) : Rickettsia-like bodies in infantile acute febrile mucocutaneous lymph-node syndrome. Lancet, 2: 42 .

Hamashima, Y., K. Tasaka, T. Hoshino, N. Nagata, F. Furukawa, T. Kao and H. Tanaka (1982): Mite-associated particles in Kawasaki disease. Lancet, 2: 266.

Ishii, A. (1975): Researches on the house clust mite and allergy in Japan. Jpn. J. Sanit. Zool., 26: $173-179$.

Ishii, A., M. Takaoka, M. Ichinoe, Y. Kabasawa and T. Ouchi (1979): Mite fauna and fungal flora in house dust from homes of asthmatic children. Allergy, 34: 379-387.

Ishii, A., T. Yatani, H. Kato and T. Fujimoto (1983): Mite fauna, house dust, and Kawasaki disease. Lancet, 2: 102-103.

Kato, H., T. Fujimoto, O. Inoue, M. Kondo, Y. Koga, S. Yamamoto, M. Shingu, K. Tominaga and Y. Sasaguri (1983): Variant strain of Propionibacterium acnes: A clue to the aetiology of Kawasaki disease. Lancet, 2: 13831387.

Lustgraaf, B. V. D. (1979): Xerophilic fungi and house-dust mites. In: Recent Advance in Acarology, Vol. 2, pp. 179-183.

Miyamoto, J., A. Ishii and M. Sasa (1975): A successful method for mass culture of the house dust mites: Dermatophagoides pteronyssinus (Troussart, 1887). Jpn. J. Exp. Med., 45: 133-138.

Shimomura, H., A. Ishii, M. Takaoka and R. Kano (1982): Collection of each stage of the house dust mite from a culture by sieving and observation of the mode of breeding. Jpn. J. Sanit. Zool., 33: 1-7 (in Japanese).

Solomon, W. R. (1975): Assessing fungus preva- 
lence in domestic interiors. J. Allergy Clin. Immunol., 56: 235-242.

Takahashi, S. and S. Tanie (1974): Airborne fungi and bronchial asthma. Jpn. J. Med. Mycol., 15: 3-10.

Ushijima, H., R. Park, K. Yoshino, K. Ohta, R. Fujii and N. Kobayashi (1983): Microorganisms in house-dust mites in Kawasaki disease. Acta Paediatr. Jpn., 25: 127-129.

van Bronswijk, J. E. M. H. and R. N. Sinha (1973): Role of fungi in the survival of Dermatophagoides (Acarina: Pyloglyphidae) in house-dust environment. Environ. Entomol., 2: 142.

Wharton, G. M. (1976): House dust mites, J. Med. Entomol., 12: 577-621.
摘 要

ヒョウヒダニ類に関連した微生物について

屋内塺のヒョウヒダ二類に関連した細菌・真菌類に ついて調べた. ダ二成虫は滅菌蒸留水で十分洗い，磨 砕した。細菌数計測, 細菌・真菌類の分離・同定は医 学病原微生物の常とう検査法に準拠した。細菌陽性の 屋内壁におけるダニ 100 匹中の細菌数は実験室培養七 ヨウヒダニで 12.7 個, 正常家庭群で 121 個以上，喘息 患児宅群で66個以上，川崎病患児宅群で 121 個であっ た．分離された細菌叢は芽胞菌・ブドウ状球菌・グラ ム陰性非酘酵性桿菌・グラム陽性コリネバクテリウム 桿菌であり，真菌類としては Aspergillus, Penicillium, Cladosporium, Alternaria, Acremonium, Paecilomyces 七酵母菌であった。 ヒョウヒダ二類に 関連した微生物は，その生存下にある常在菌に左石さ れると思われる. かつ正常家庭群, 喘息患児宅群之川 崎病患児宅群の閒で, 今回の成績では顕著な差異はみ られなかった。 